\title{
IDENTIFIKASI CITRA GARIS TELAPAK TANGAN MENGGUNAKAN METODE LINEAR DISCRIMINANT ANALYSIS DENGAN PROBABILITAS NAÏVE BAYESIAN
}

\author{
Bayu Pradinta ${ }^{1}$, Ernawati ${ }^{2}$, Endina Putri Purwandari ${ }^{3}$ \\ 1,2,3 Program Studi Teknik Infomatika, Fakultas Teknik, Universitas Bengkulu. \\ Jl. WR. Supratman Kandang Limun Bengkulu 38371A INDONESIA \\ (telp: 0736-341022; fax: 0736-341022) \\ ${ }^{1}$ bayupradinta@gmail.com, \\ ${ }^{2}$ ernawati@unib.ac.id, \\ ${ }^{3}$ endinaputri@unib.ac.id
}

\begin{abstract}
Abstrak : Pencocokan citra merupakan suatu cara untuk mengidentifikasi dan mengukur kesamaan citra. Penelitian ini menggunakan teknologi biometrik yaitu sistem yang melakukan pencocokan citra berdasarkan bagian tubuh manusia dengan cara mencocokkan antara citra uji yang diterima dengan citra latih. Citra yang digunakan adalah telapak tangan. Penggunaan telapak tangan dikarenakan telapak tangan memiliki karakteristik yang unik, sulit dipalsukan dan cenderung stabil. Penelitian ini membangun sebuah aplikasi identifikasi citra garis telapak tangan berbasis tekstur dengan metode linear discriminant analysis untuk ekstraksi ciri dan metode nä̈ve bayesian untuk menghitung peluang kemiripan citra uji dengan citra latih. Citra yang digunakan sebagai objek penelitian adalah citra telapak tangan manusia bagian kanan dari CASIA Palmprint Image Database dan yang diambil langsung dari orang sekitar. Aplikasi ini dibangun dalam bahasa pemrograman Matlab R2016a dan dirancang dengan Unified Model Language (UML). Metode pengembangan sistem yang digunakan adalah protoyping. Hasil yang diperoleh pada penelitian ini adalah nilai akurasi sebesar 95\% untuk pengujian citra uji terhadap citra latih, 93.4\% untuk citra uji dengan noise salt and pepper 0.005 dan 93,4\% untuk pengujian citra uji dengan Gaussian filter 2.5 .

Kata Kunci : Pencocokan Citra, Citra Garis Telapak tangan, Linear Discriminant Analysis, Naïve Bayesian.
\end{abstract}

\begin{abstract}
Image matching is a way to identify and measure the similarity image. This research uses biometric technology that system performs image matching based on parts of the human body by matching between the test images received by the trained image. The image use is palm. The use of palm because of the palm has unique characteristics, hard to forge and tend to be stable. This study build an image identification applications palmprint with texture-based linear discriminant analysis method for feature extraction and naïve Bayesian method to calculate the probability similarity of test images with train images. Image that used as an object of research is the image of human hands right part from CASIA Palmprint Image Database and taken directly from the people around. This application is built in programming language Matlab R2016a and is designed with the Unified Model Language (UML). System development
\end{abstract}

method used is protoyping. The results obtained in this research is the accuracy value of 95\% for testing the test images to the image of training, 93,4\% for the test images with salt and pepper noise 0.005 and $93,4 \%$ for testing the test images with the Gaussian filter 2.5 .

Keywords: Image Matching, Palmprint Image, Linear Discriminat Analysis, Nä̈ve Bayesian.

\section{PENDAhuluan}

Kemampuan sistem pengenalan diri yang mampu mengenali target secara tepat dan akurat dapat difungsikan untuk meningkatkan keamanan sistem. Beberapa metode yang masih banyak diterapkan untuk mengidentifikasi seseorang 
Jurnal Pseudocode, Volume IV Nomor 2, September 2017, ISSN 2355-5920 www.ejournal.unib.ac.id/index.php/pseudocode

adalah metode konvensional, yaitu sesuatu yang diingat oleh user seperti Personal Identification Number (PIN) dan password. Namun metode ini tidak lagi bisa diandalkan karena PIN dan password bisa dilupakan oleh user maupun diketahui oleh orang lain. Sistem biometrika diharapkan mampu meminimalisasi kelemahankelemahan yang ada pada sistem identifikasi konvensional. Beberapa sistem biometrika telah dikembangkan dalam beberapa tahun. Namun, beberapa dari sistem tersebut memiliki kekurangan masing-masing.

Telapak tangan memiliki karakteristik yang unik, diantaranya ciri-ciri geometri seperti: panjang, lebar, dan area telapak tangan, garis-garis prinsip seperti garis hati, garis kepala, dan garis kehidupan, garis-garis kust/lemah, titik delta, dan ciri-ciri minusi [1]. Garis-garis prinsip dan kusut memiliki beberapa kelebihan dibandingkan dengan ciri-ciri yang dihasilkan biometrik lainya seperti dapat diperoleh dari citra resolusi rendah, sulit dipalsukan, dan ciri-ciri garis telapak tangan bersifat stabil karena sedikit mengalami perubahan dalam kurun waktu lama. Dengan adanya karakteristik yang unik ini maka telapak tangan dapat digunakan sebagai alat verifikasi identitas seserorang dengan mencocokan data yang terdapat dalam database dengan data yang dimasukan.

Metode untuk ekstrakasi fitur yang paling popular adalah Principal Component Analysis (PCA). Namun demikian PCA memiliki kelemahan yaitu pemisah antar kelas yang kurang optimal [2].

Linear Discriminant Analysis (LDA) merupakan metode yang digunakan untuk mengatasi kekurangan PCA. Pengurangan dimensi pada LDA dilakukan dengan cara memaksimalkan nilai Between-Class Scatter dan meminimalkan Within-Class Scatter. Filter Gaussian adalah salah satu filter linear dengan nilai pembobotan untuk setiap anggotanya dipilih berdasarkan bentuk fungsi Gaussian. Filter ini sangat baik untuk menghilangkan noise yang bersifat sebaran normal [3].

Metode pengukuran berbasis peluang menggunakan Naive Bayesian termasuk metode yang sederhana. Beberapa kelebihan dari teori Naive Bayesian adalah mudah untuk dipahami, hanya memerlukan pengkodean yang sederhana dan lebih cepat dalam penghitungan [4]. Proses segmentasi citra dilakukan dengan memanfaatkan metode Region of Interest (ROI). Region of Interest (ROI) memungkinkan pengguna untuk mengakses bagian tertentu dari sebuah citra digital untuk diolah secara berbeda [5].

Untuk itu maka akan dilakukan penelitian deteksi telapak tangan yang memfokuskan pada masalah akurasi dan kecepatan aplikasi melakukan pencocokan citra telapak tangan menggunakan metode Linear Discriminant Analysis (LDA) dengan probabilitas Naive Bayesian.

\section{LANDASAN TEORI}

\section{A. Linear Discriminant Analysis (LDA)}

Metode untuk ekstarkasi fitur yang paling popular adalah Principal Component Analysis (PCA). Namun demikian PCA memiliki kelemahan yaitu pemisah antar kelas yang kurang optimal. Linear Discriminant Analysis (LDA) merupakan metode yang digunakan untuk mengatasi kekurangan PCA. Pengurangan dimensi pada LDA dilakukan dengan cara memaksimalkan nilai Between-Class Scatter dan meminimalkan 
Jurnal Pseudocode, Volume IV Nomor 2, September 2017, ISSN 2355-5920

www.ejournal.unib.ac.id/index.php/pseudocode

Within-Class Scatter. PCA dan LDA mempunyai perbedaan yang sangat jelas, pengklasifikasian terhadap ciri dapat dilakukan oleh PCA, pengklasifikasian terhadap data dapat dilakukan dengan LDA. Pada ekstraksi fitur dengan LDA, data set lokasinya tetap, namun kelas yang dibentuk menjadi lebih terpisah, kondisi ini disebabkan oleh jarak antar data pelatihan dalam satu kelas menjadi lebih kecil [3].

LDA bekerja berdasarkan analisa matrik penyebaran (scatter matrix analysis) yang bertujuan menemukan suatu proyeksi optimal yang dapat memproyeksikan data input pada ruang dengan dimensi yang lebih kecil dimana semua pola dapat dipisahkan semaksimal mungkin. Karenanya untuk tujuan pemisahan tersebut maka LDA akan mencoba untuk memaksimalkan penyebaran data-data input diantara kelas-kelas yang berbeda sekaligus juga meminimalkan penyebaran input pada kelas yang sama. Perbedaan antar kelas direpresentasikan oleh matriks $S_{B}$ (scatter between class) dan perbedaan dalam kelas direpresentasikan oleh matriks $S_{W}$ (scatter within class).

Matrix Scatter dalam kelas $S_{w}$, dan matrix scatter antar kelas $S_{B}$ didefinisikan masing-masing sebagai berikut:

$S_{w}=\sum_{i=1}^{c} \sum_{x_{k} \in X_{i}}\left(x_{k}-\mu_{i}\right)\left(x_{k}-\mu_{i}\right)^{T}$

$S_{B \mathrm{~S}}=\sum_{i=1}^{c} N_{i}\left(x_{k}-\mu_{i}\right)\left(x_{k}-\mu_{i}\right)^{T}$

Keterangan :

$$
\begin{aligned}
& S_{w} \text { : matrix within scatter } \\
& c: \text { jumlah kelas } \\
& x_{k} \text { : gambar ke- } k \\
& N \text { : jumlah gambar pada kelas ke- } i \\
& \mu \text { : rata-rata total dari keseluruhan gambar } \\
& \mu_{i} \text { :rata-rata dari kelas ke- } i
\end{aligned}
$$

Kriteria ini menghasilkan solusi dengan persamaan berikut:

$$
S_{B}=S_{W} \Psi \Lambda
$$

Keterangan :

$S_{B}$ : matrix between scatter

$S_{w}$ : matrix within scatter

$\Psi$ : matrix eigenvector

$\Lambda$ : adalah matrix diagonal nilai eigen

Dengan kata lain akan dicari eigenvector dan eigenvalue dari matix $\mathrm{C}$ yang merupakan kombinasi within dan between scatter matrix seperti pada persamaan 2.3. Kembali dilakukan pemilihan sebanyak 1 kolom eigenvector dari $\Psi$ yang berasosiasi dengan nilai-niai eigen terbesar. Pemilihan $l$ kolom eigenvector ini menghasilkan matrix proyeksi $\Psi_{l}$ yang selanjutnya digunakan untuk ekstraksi feature seperti halnya pada PCA.

\section{B. Naïve Bayesian}

Model pengukuran kemiripan objek berbasis peluang dengan mempertimbangkan peluang parameter yang melekat pada suatu objek seperti ciri citra latih dan ciri citra uji. Salah satu metode pengukuran kemiripan berbasis peluang yang sering digunakan adalah Naive Bayesian. Metode pengukuran kemiripan menggunakan Naive Bayesian termasuk metode yang sederhana, namun metode itu telah banyak digunakan untuk melakukan klasifikasi kedokteran, biometrika, klasfikasi teks dan masih banyak lagi [6]. Naive Bayesian menggunakan distribusi Gaussian untuk menangani atribut kontinu. Distribusi Gaussian ini mempertimbangkan dua parameter penting yaitu, rata-rata $\mu$ dan varian $\sigma$. Gaussian yang digunakan untuk pengukuran kemiripan Naive Bayesian adalah menggunakan Persamaan [2].

$$
\begin{gathered}
\mathrm{P}\left(\mathrm{X}_{\mathrm{i}}=\mathrm{x}_{\mathrm{i}} \mid \mathrm{Y}=\mathrm{y}_{\mathrm{i}}\right)= \\
\frac{1}{\sqrt{2 \pi \sigma_{i j}}} \exp \left[-\frac{1}{2}\left(\frac{x_{i}-\mu_{i j}}{\sigma_{i j}}\right) \quad{ }^{2}\right]
\end{gathered}
$$

Keterangan :

$P$ : probabilitas dari atribut $x i$ 
Jurnal Pseudocode, Volume IV Nomor 2, September 2017, ISSN 2355-5920 www.ejournal.unib.ac.id/index.php/pseudocode

$i$ : indek untuk nilai dari atribut

$j$ : indek kelas

$Y$ : merepresentasikan kelas yang dicari

$x$ : data uji

$\mu$ : nilai rata-rata ciri citra

$\sigma:$ nilai standar deviasi dari ciri citra

Dengan $P$ merupakan nilai probabilitas dari citra latih terhadap citra uji. Langkah pertama yaitu mencari nilai hasil bagi 1 dengan $\sqrt{2} \pi$ dikali standar deviasi dari citra latih kemudian dikali dengan nilai eksponensial dari perkalian antara $-\frac{1}{2}$ dengan kuadrat dari hasil bagi dari citra uji dikurang ciri dari citra latih dibagi standar devisasi dari citra latih .

Misalkan diketahui 6 buah citra yang telah dikelompokkan menjadi 3 kelas, masing-masig mempunyai 2 data dari 3 ciri yang unik sebagaimana terlihat pada Tabel 2.1.

Tabel 2. 1 Data Ciri 3 Kelas Citra

\begin{tabular}{|c|c|c|c|c|}
\hline Citra & Kelas & Ciri 1 & Ciri 2 & Ciri 3 \\
\hline 1 & A & 20 & 60 & 30 \\
\cline { 3 - 5 } 2 & & 19 & 55 & 35 \\
\hline 3 & \multirow{2}{*}{$\mathrm{B}$} & 10 & 70 & 32 \\
\cline { 3 - 5 } 4 & & 12 & 72 & 28 \\
\hline 5 & $\mathrm{C}$ & 10 & 60 & 40 \\
\cline { 3 - 5 } 6 & & 11 & 40 & 43 \\
\hline
\end{tabular}

Jika ada satu citra yang akan diuji dengan ciri ke-1 = 14, ciri ke-2 = 60 dan ciri ke-3 = 38, dengan menggunakan metode Naïve Bayesian tentukan masuk kelas mana citra tersebut. Untuk melakukan klasifikasi citra menggunakan Nä̈ve Bayesian, maka perlu dihitung rata-rata dan standar deviasi tiap kelas untuk masing-masing ciri. Rata-rata dan standar deviasi dari 3 kelas citra dengan 3 ciri dapat dilihat pada Tabel 2.2 dan Tabel 2.3.
Tabel 2. 2 Rata-rata Ciri Citra 3 Kelas

\begin{tabular}{|c|c|c|c|}
\hline \multirow{2}{*}{ Kelas } & \multicolumn{3}{|c|}{ Rata-rata } \\
\cline { 2 - 4 } & Ciri 1 & Ciri 2 & Ciri 3 \\
\hline A & 19.5 & 57.5 & 32.5 \\
\hline B & 11 & 71 & 30 \\
\hline C & 10.5 & 50 & 41.5 \\
\hline
\end{tabular}

Tabel 2. 3 Standar Deviasi Ciri Citra 3 Kelas

\begin{tabular}{|c|c|c|c|}
\hline \multirow{2}{*}{ Kelas } & \multicolumn{3}{|c|}{ Standar Deviasi } \\
\cline { 2 - 4 } & Ciri 1 & Ciri 2 & Ciri 3 \\
\hline A & 0.70711 & 3.5355 & 3.5355 \\
\hline B & 1.4142 & 1.4142 & 2.8284 \\
\hline C & 0.70711 & 14.142 & 2.1213 \\
\hline
\end{tabular}

Peluang kelas A terhadap semua kelas adalah jumlah data kelas a dibagi dengan jumlah data semua kelas, dalam hal ini adalah 2/6 $=0.33$. Begitu juga dengan peluang kelas B terhadap semua kelas masing-masing juga 0.33 , sehingga

$$
\begin{aligned}
& \mathrm{P}(\text { Kelas }=\mathrm{A})=\frac{2}{6}=0.33 \\
& \mathrm{P}(\text { Kelas }=\mathrm{B})=\frac{2}{6}=0.33 \\
& \mathrm{P}(\text { Kelas }=\mathrm{C})=\frac{2}{6}=0.33
\end{aligned}
$$

Data rata-rata dan standar deviasi sebagaimana terlihat pada Tabel 2.2 dan 2.3 digunakan untuk menghitung peluang kemiripan tiap-tiap ciri terhadap citra kelas. Berdasarkan pesamaan (2.4), maka nilai peluang tiap ciri-ciri data uji terhadap masing-masing karakteristik kelas A dapat dihitung sebagaimana berikut ini

$\mathrm{P}($ Kelas A/Ciri ke-1 $=14)=\frac{1}{\sqrt{2 * 3.14} * 0.707711} *$

$e^{-0.5\left(\frac{14-119.5}{0.70711}\right)^{2}}=4.11270063676419 \mathrm{E}-14$

$\mathrm{P}($ Kelas A/Ciri ke-2=60 $)=\frac{1}{\sqrt{2 * 3.14} * 3.5355}$ *

$e^{-0.5\left(\frac{60-57.5}{3.5355}\right)^{2}}=0.0879005416323996$

$\mathrm{P}($ Kelas A/Ciri ke- $3=38)=\frac{1}{\sqrt{2 * 3.14} * 3.5355} *$

$e^{-0.5\left(\frac{38-32.5}{3.5355}\right)^{2}}=0.033656492064405$

Peluang kemiripan data citra uji terhadap citra kelas A dapat dihitung sebagaimana berikut ini 
Jurnal Pseudocode, Volume IV Nomor 2, September 2017, ISSN 2355-5920

www.ejournal.unib.ac.id/index.php/pseudocode

$\mathrm{P}($ Kelas $=\mathrm{A} /$ Data uji $)=\mathrm{P}($ Kelas $=\mathrm{A} /$ Ciri

$=14) * \mathrm{P}($ Kelas $=\mathrm{A} /$ Ciri $2=60) * \mathrm{P}($ Kelas $=\mathrm{A} /$ Ciri

$3=38) * \mathrm{P}($ Kelas $=\mathrm{A})=$

4.11270063676419E14*0.0879005416323996*0.0

$33656492064405 * 0.33=4.05570392768 \mathrm{E}-17$

Dengan cara yang sama, maka nilai peluang tiap ciri-ciri data uji terhadap masing-masing karakteristik pada kelas B dapat dihitung sebagaimana berikut ini

$\mathrm{P}\left(\right.$ Kelas $\mathrm{B} /$ Ciri $\quad$ ke-1=14) $=\frac{1}{\sqrt{2 * 3.14 * 1.4142}} *$ $e^{-0.5\left(\frac{14-11}{1.4142}\right)^{2}}$

$$
=0.029740117461812
$$

$\mathrm{P}($ Kelas $\quad \mathrm{B} /$ Ciri $\quad \mathrm{ke}-2=60)=\frac{1}{\sqrt{2 * 3.14} * 1.412} *$ $e^{-0.5\left(\frac{60-71}{1.4142}\right)^{2}}$

$=2.05635031838209 \mathrm{E}-14$

$\mathrm{P}\left(\right.$ Kelas B/Ciri ke-2=38) $=\frac{1}{\sqrt{2 * 3.14} * 2.8284} *$ $e^{-0.5\left(\frac{38-30}{2.8284}\right)^{2}}$

$$
=0.00258028243954
$$

Peluang kemiripan data citra uji terhadap citra kelas B dapat dihitung sebagaimana berikut ini

$\mathrm{P}($ Kelas $=\mathrm{B} /$ Data $\quad$ uji $) \quad=\quad \mathrm{P}($ Kelas $=\mathrm{A} /$ Ciri $1=14) * \mathrm{P}($ Kelas $=\mathrm{A} /$ Ciri $2=60) * \mathrm{P}($ Kelas=A/Ciri $3=38) * \mathrm{P}($ Kelas $=\mathrm{B})$

$0.029740117461812 * 2.05635031838209 \mathrm{E}-$

$14 * 2.0563$

5031838209E-14 = 5.26763532066598E-19

Dengan cara yang sama dihitung peluang tiap ciri-ciri data uji terhadap masing-masing karakteristik pada kelas C. Peluang kemiripan data uji terhadap kelas $\mathrm{C}$ adalah

$\mathrm{P}($ Kelas $=\mathrm{C} /$ Data Uji $)=9.53957340552974 \mathrm{E}-10$

Untuk membuat keputusan akhir data uji masuk dalam kelas A, B atau C. Data peluang citra uji terhadap kelas A, B dan C dibandingkan, yang mempunyai peluang paling besar adalah kelas yang paling mirip. Dalam contoh ini yang mempunyai peluang maksimal adalah kelas C, nilai peluangnya adalah 9.53957340552974E-10.

\section{III.METODE PENELITIAN}

\section{A. Dataset Penelitian}

Data set penelitian dengan sampel 180 citra telapak tangan manusia yang diambil dari 30 objek terdiri dari 120 sampel yang diambil secara acak dari lingkungan sekitar dan 60 diambil dari CASIA Palmprint Image Database. Dari setiap objek diambil 6 sampel yang dipengaruhi oleh pencahayaan serta sudut pengambilan gambar yang berbeda.

\section{B. Metode Pengembangan Sistem}

Metode pengembangan sistem yang akan digunakan dalam penelitian ini adalah metode prototyping. Prototyping mengerjakan fase analisis, perancangan, dan implementasi secara bersamaan, dan ketiga fase tersebut dikerjakan berulang hingga sistem lengkap. Dengan metodologi ini, dasar dari analisis dan perancangan dikerjakan, dan segera mulai mengerjakan sistem prototipe, suatu program “quick-and-dirty" yang menyediakan sejumlah fitur minimum [7]. Metodologi prototyping ditunjukkan gambar 3.1.

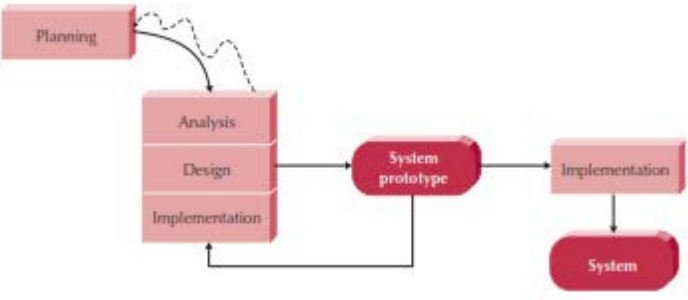

Gambar 3. 1 Metodologi berbasis prototyping

\section{Metode Pengujian Sistem}

\section{White Box Testing}

Dalam pengujian white box, penulis akan meneliti kode-kode program yang ada dan akan 
Jurnal Pseudocode, Volume IV Nomor 2, September 2017, ISSN 2355-5920 www.ejournal.unib.ac.id/index.php/pseudocode

menganalisis apakah ada kesalahan atau tidak. Pada penelitian ini akan menggunakan pengujian white box jenis basis path testing. Basis path testing adalah salah satu teknik pengujian yang didasarkan pada aliran logika yang diambil dari program atau sistem.

\section{Black Box Testing}

Black box testing adalah sebuah pengujian kondisi yang dibangun berdasarkan fungsional dari sistem. Pada penelitian ini akan menggunakan pengujian black box jenis Equivalence Partioning, yaitu metode yang membagi domain masukan dari suatu program ke dalam kelas-kelas data berdasarkan pada premis masukan dan keluaran dari suatu komponen yang dipartisi ke dalam kelas-kelas menurut spesifikasi dari komponen tersebut, yang akan diperlukan sama oleh komponen tersebut.

\section{Metode Uji Kelayakan Sistem}

Unjuk kerja suatu sistem biometrika dinyatakan dengan Decision Error Rate (rasio kesalahan), yaitu False Matching Rate/FMR (Rasio Kesalahan Pencocokan) dan False Non Matching Rate/FNMR (Rasio Kesalahan Ketidakcocokan) [8].

Kesalahan dihitung dengan menggunakan persamaan [12], berikut :

FMR/Rasio Kesalahan Pencocokan = (Jumlah Kesalahan)/(Jumlah Keseluruhan Proses) $\times 100 \%$

Selain itu untuk menyatakan tingkat kesuksesan pengenalan suatu sistem biometrika (bukan tingkat kesalahan) disebut sebagai Genuine Acceptance Rate (GAR) dan dihitung menggunakan persamaan berikut :

GAR $=1-$ FMR atau GAR $=1-$ FNMR

Kinerja biometrika ditentukan berdasarkan kedua parameter tersebut. Jika tingkat kesalahannya tinggi, maka sistem biometrika harus ditinjau apakah memang ada kesalahan algoritma atau kesalahan pembacaan sensor atau memang tipe biometrika itu sendiri tidak bisa memenuhi kekhasan [9]. Umumnya semakin besar ukuran database atau jumlah pengguna dalam database, maka bagian tumpang tindih akan semakin besar yang artinya FMR/FNMR meningkat dan demikian pula sebaliknya [9].

\section{IV.ANALISIS DAN PERANCANGAN}

\section{A. Identifikasi Masalah}

Suatu aplikasi identifikasi citra garis telapak tangan biasa menggunakan metode seperti Principal Component Analysis (PCA), Jaringan Syaraf Tiruan, Transformasi Wavelet, Hidden Markov Model (HMM), dan Linear Discriminant Analysis (LDA). Namun untuk meningkatkan akurasi pencocokan garis telapak tangan, metode tersebut bisa digabungkan dengan metode-metode lain. Metode lain yang dapat ditambahkan tersebut misalnya saja metode untuk melakukan segmentasi terhadap citra yang akan dideteksi dan metode untuk meningkatkan kualitas dari citra tersebut. Penelitian ini menggunakan metode Region of Interest (ROI) untuk melakukan segmentasi dan metode Gaussian Filter untuk meningkatkan kualitas citra. Dengan adanya tambahan metodemetode tersebut diharapkan dapat meningkatkan tingkat akurasi pada saat pencocokan citra.

\section{B. Analisis Alur Kerja Sistem}

Alur sistem merupakan hasil analisis perancangan tahapan kerja sistem yang akan dibangun. Alur ini dimulai dari user memasukkan (input) data sampai menghasilkan keluaran (output). Dalam sistem ini, input-nya berupa citra telapak tangan manusia dan informasi biodata citra 
Jurnal Pseudocode, Volume IV Nomor 2, September 2017, ISSN 2355-5920 www.ejournal.unib.ac.id/index.php/pseudocode

tersebut. Sedangkan untuk output adalah citra hasil pencocokan telapak tangan yang memiliki peluang terbesar.

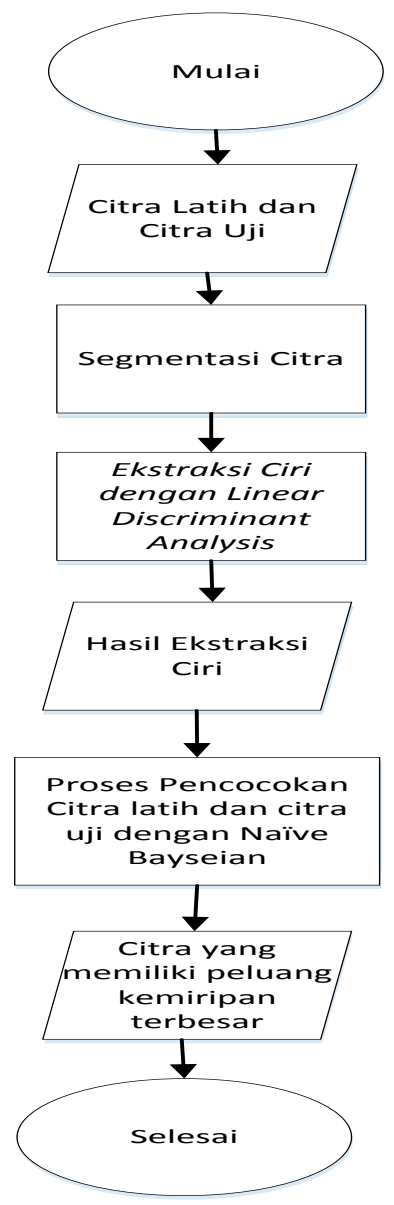

Gambar 4. 1 Diagram Alir Sistem

\section{Analisis Fungsional}

Analisis fungsional berarti melakukan analisis dari fungsi-fungsi pada sistem yang akan dibangun. Fungsi-fungsi pada sistem yang dimaksud adalah fitur-fitur yang terdapat didalam sistem. Berikut adalah beberapa fitur yang terdapat pada sistem :

a. Sistem yang dibangun mampu melakukan segmentasi dengan metode Region Of Interest (ROI ) dari citra yang diinputkan oleh user.

b. Sistem yang dibangun dapat melakukan pencocokan citra telapak tangan dengan menggunakan metode ekstraksi Linear Discriminant Anaysis dan menggunakan metode Naïve Bayesian untuk mengukur peluang kemiripan antara citra uji dengan citra latih.

c. Sistem yang dibangun dapat menampilkan output berupa identitas citra. Identitas citra tersebut sebelumnya telah disimpan kedalam database oleh user.

\section{PEMBAHASAN}

\section{A. Implementasi Interface}

\section{Menu Utama}

Halaman utama pada aplikasi ini muncul pertama kali saat aplikasi ini dijalankan. Tampilan dari menu utama aplikasi yang dapat dilihat pada Gambar 5.1.

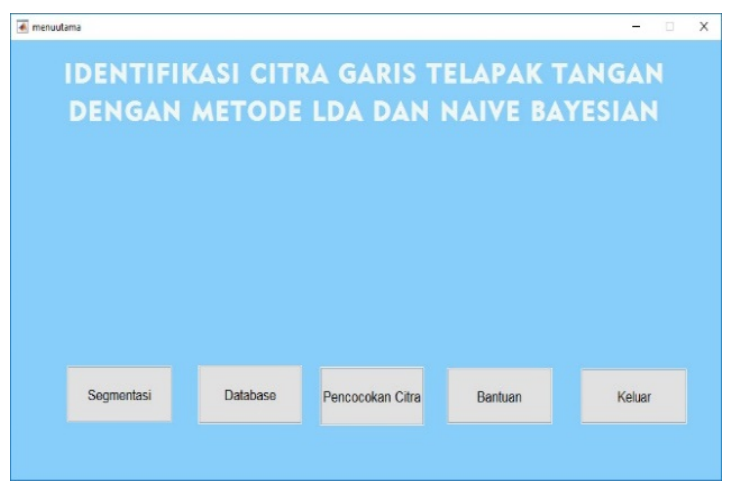

Gambar 5. 1 Menu Utama

Dapat dilihat pada Gambar 5.1 merupakan tampilan menu utama. Pada menu utama aplikasi menggunakan beberapa tombol yaitu tombol Segmentasi, tombol Database, tombol Pencocokan Citra, tombol Bantuan dan tombol Keluar. Latar belakang gambar menu utama menggunakan gambar background.jpg.

\section{Menu Segmentasi}

Menu segmentasi akan muncul setelah memilih tombol Segmentasi pada menu utama Tampilan dari Menu Segmentasi yang dapat dilihat pada Gambar 5.2. 
Jurnal Pseudocode, Volume IV Nomor 2, September 2017, ISSN 2355-5920 www.ejournal.unib.ac.id/index.php/pseudocode

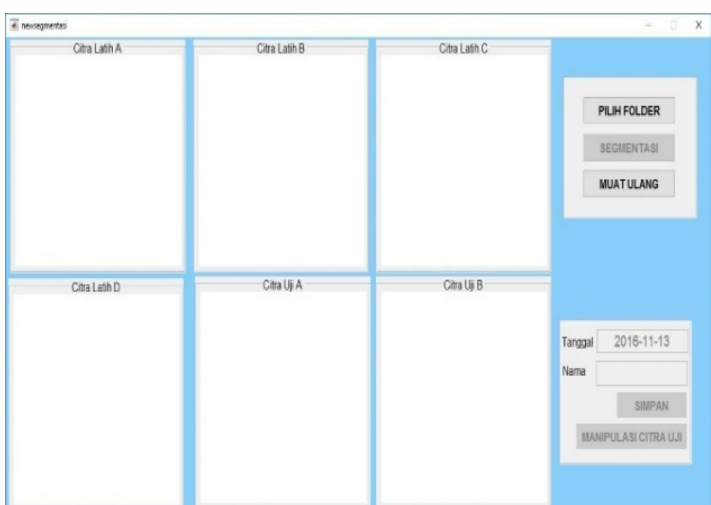

Gambar 5. 2 Menu Segmentasi

Pada menu Segmentasi terdapat tombol Pilih Folder yang digunakan untuk memilih folder citra telapak tangan yang akan disegmentasi, setelah folder citra telah terpilih maka citra yang ada pada folder tersebut akan ditampilkan pada 6 axes yang tersedia pada interface, seperti pada gambar berikut ini.

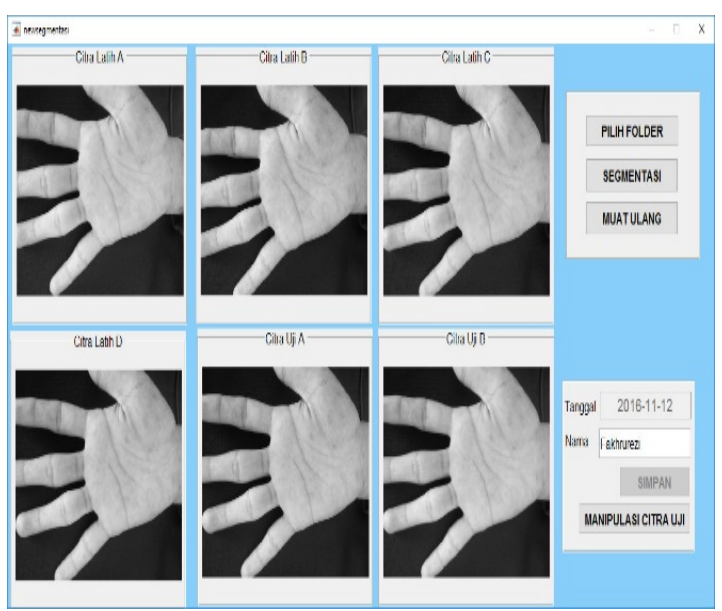

Gambar 5. 3 Tampilan interface setelah memilih folder citra

Setelah memilih folder citra, tekan tombol segmentasi untuk melakukan segmentasi citra. Hasil dari segmentasi citra akan menggantikan posisi citra telapak tangan sebelum segmentasi, seperti pada Gambar 5.4 berikut ini.

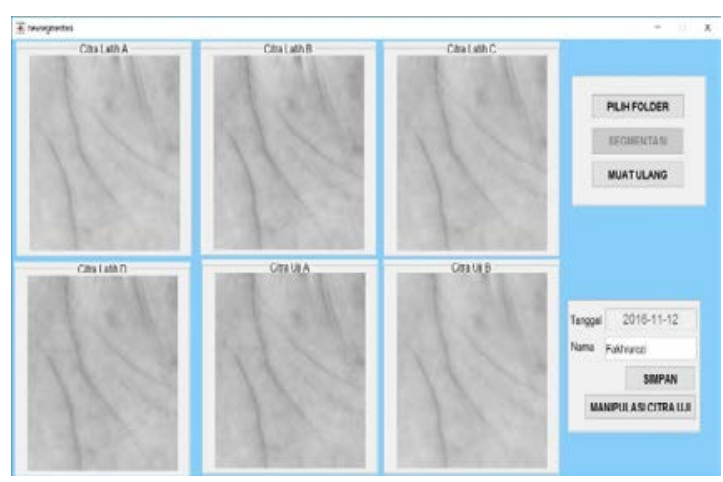

Gambar 5. 4 Hasil Segmentasi

Pada Gambar 5.4 terlihat bahwa keenam citra telapak tangan telah tersegmentasi secara serentak, setelah proses segmentasi selesai maka proses selanjutnya adalah menyimpan citra hasil segmentasi. Tulis nama citra pada kolom nama, kemudian tekan tombol Simpan. Citra dengan nama Citra Latih A, Citra Latih B, Citra Latih C, dan Citra Latih D akan tersimpan pada database sesuai dengan nama yang telah diinputkan dan tersimpan pada folder citra latih dengan nama file sesuai dengan nomor urut citra terakhir yang ada di folder citra latih sedangkan citra dengan nama Citra Uji A dan Citra uji B akan tersimpan di folder Citra Uji dengan nama file yang telah diinputkan pada kolom nama sebelumnya. Tombol manipulasi citra berfungsi untuk memanipulasi citra dengan menambahkan noise ataupun blur pada citra uji seperti Gambar 5.5 dan Gambar 5.6 .

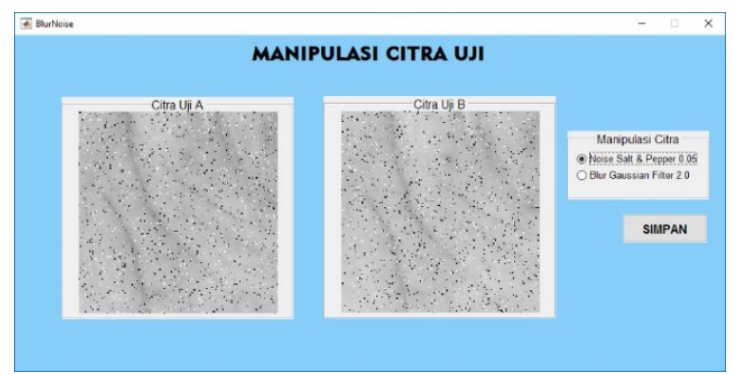

Gambar 5. 5 Citra Uji dengan Noise Salt and Pepper 
Jurnal Pseudocode, Volume IV Nomor 2, September 2017, ISSN 2355-5920 www.ejournal.unib.ac.id/index.php/pseudocode

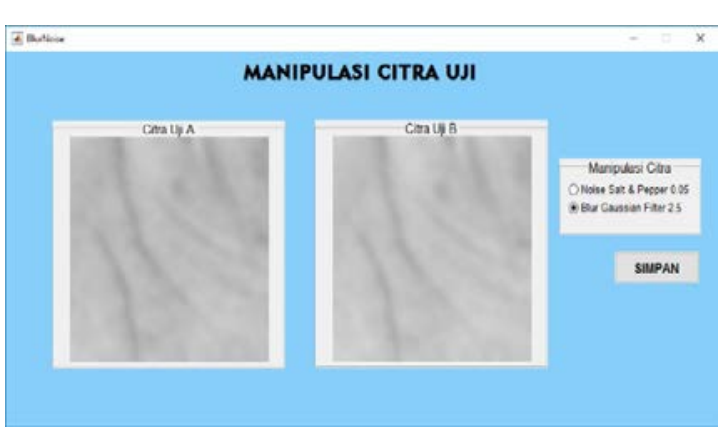

Gambar 5. 6 Citra Uji dengan Blur Gaussian Filter

Citra Uji A dan Citra Uji B yang ada pada menu segmentasi akan ditransfer ke menu manipulasi citra uji. Pada menu ini user dapat memilih jenis manipulasi yang diinginkan pada radio button. Setelah itu user dapat menyimpan hasil manipulasi cittra dengan menekan tombol simpan.

\section{Menu Database}

Menu database akan tampil setelah menekan tombol Database pada menu utama. Berikut adalah tampilan dari Menu database yang dapat dilihat pada Gambar 5.7.

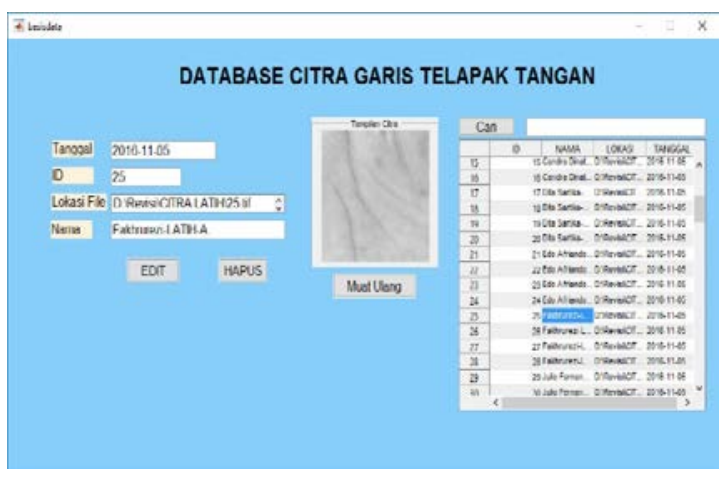

Gambar 5. 7 Menu Database

Pada Gambar 5.7 terlihat daftar citra latih yang tersimpan di database pada tabel. Ketika memilih salah satu dari citra yang ada pada tabel maka data citra yang tepilih akan muncul. Tombol edit berfungsi untuk mengubah data nama citra, sedangkan tombol hapus berfungsi untuk menghapus data citra.

\section{Menu Pencocokan Citra}

Menu pencocokan citra akan tampil setelah menekan tombol pencocokan citra pada menu utama. Tampilan dari Menu pencocokan citra yang dapat dilihat pada Gambar 5.8.

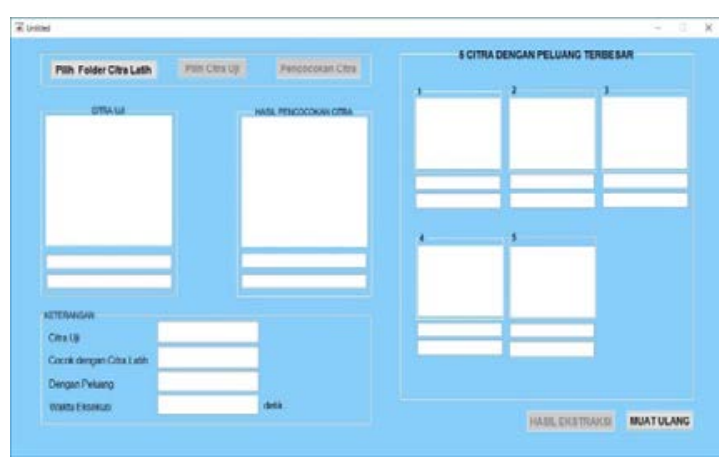

Gambar 5. 8 Menu Pencocokan Citra

Pada menu pencocokan citra terdapat tombol Pilih Folder Citra Latih yang digunakan untuk memilih folder citra latih, setelah itu tekan tombol Pilih Citra Uji untuk memilih citra yang akan diujikan dengan citra yang ada di folder citra latih, ketika citra uji terpilih, maka citra yang terpilih akan tampil pada axes citra uji pada interface seperti Gambar 5.9 berikut.

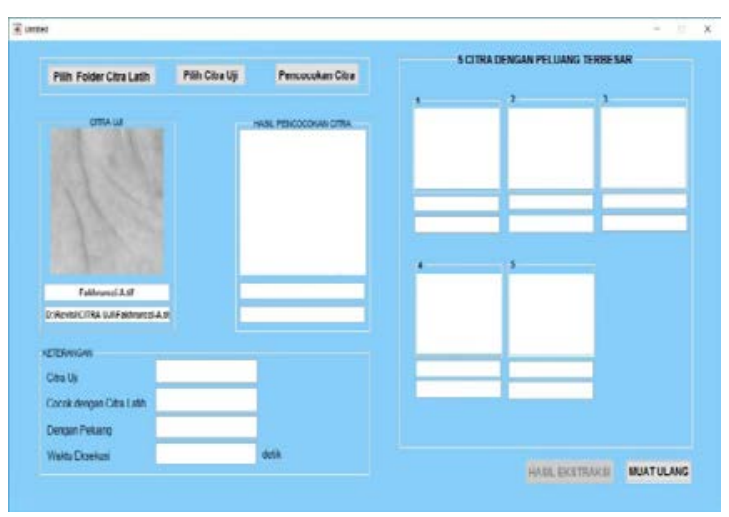

Gambar 5. 9 Pilih Citra Uji

Pada Gambar 5.9 terlihat citra uji tampil pada interface beserta dengan nama file dan lokasi file citra uji. Setelah memilih citra uji, tekan tombol Pencocokan Citra untuk melakukan proses pencocokan citra uji dengan citra latih yang ada di folder citra latih. Jika proses pencocokan citra 
Jurnal Pseudocode, Volume IV Nomor 2, September 2017, ISSN 2355-5920

www.ejournal.unib.ac.id/index.php/pseudocode

telah selesai maka citra latih yang cocok dengan citra uji akan tampil pada interface beserta dengan nama file dalam database dan lokasi file-nya. Pada kolom keterangan ditampilkan nilai peluang kemiripan yang diperoleh dari citra latih yang cocok dan lama waktu yang dibutuhkan untuk melakukan proses pencocokan citra. Pada bagian kanan interface juga ditampilkan 5 citra latih yang memiliki peluang terbesar cocok dengan citra uji beserta dengan nama file-nya dalam database dan nilai peluang masing-masing citra tersebut, seperti Gambar 5.10 berikut.

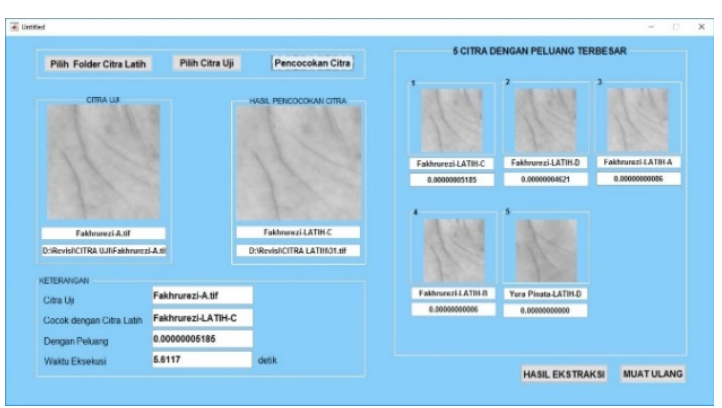

Gambar 5. 10 Hasil Pencocokan Citra

Untuk melihat hasil ekstraksi citra dapat dilakukan dengan menekan tombol hasil ektraksi. Sistem akan menampilkan hasil ekstraksi semua citra latih, citra uji, dan citra latih yang cocok dengan citra uji seperti pada Gambar 5.11:

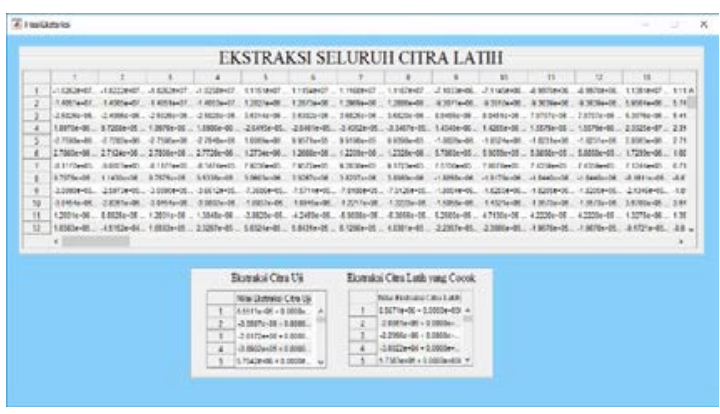

Gambar 5. 11 Hasil Ekstraksi

\section{Menu Bantuan}

Menu bantuan akan tampil setelah menekan tombol Bantuan pada menu utama. Berikut adalah tampilan dari Menu Bantuan yang dapat dilihat pada Gambar 5.12.

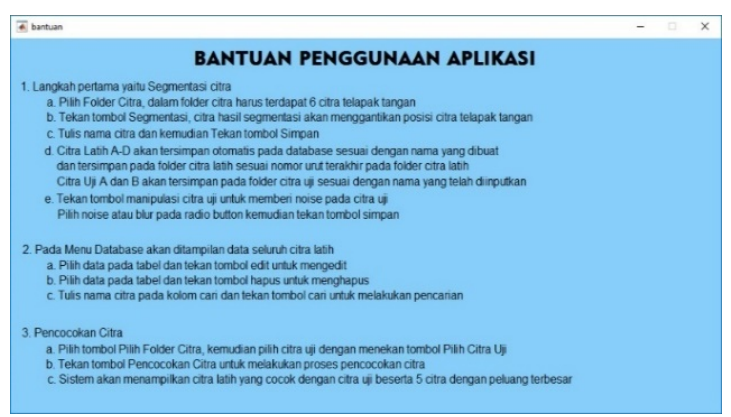

Gambar 5. 12 Menu Bantuan

\section{B. HASIL PENGUJIAN}

Pengujian yang pertama adalah pengujian terhadap metode Linear Discriminant Analysis (LDA) dan Nä̈ve Bayesian dengan menggunakan 180 citra, dimana 180 citra tersebut terdiri dari 120 citra latih dan 60 citra uji. Pengujian ini ditujukan untuk melakukan proses pencocokan citra telapak tangan yang telah dipilih sebelumnya pada menu segmentasi yang kemudian diinputkan kedalam sistem. Inputan yang diuji merupakan citra uji dengan berbagai variasi keadaan. Gambar 5.13 berikut merupakan hasil dari citra uji yang berhasil dikenali dengan tepat terhadap citra latih nya :

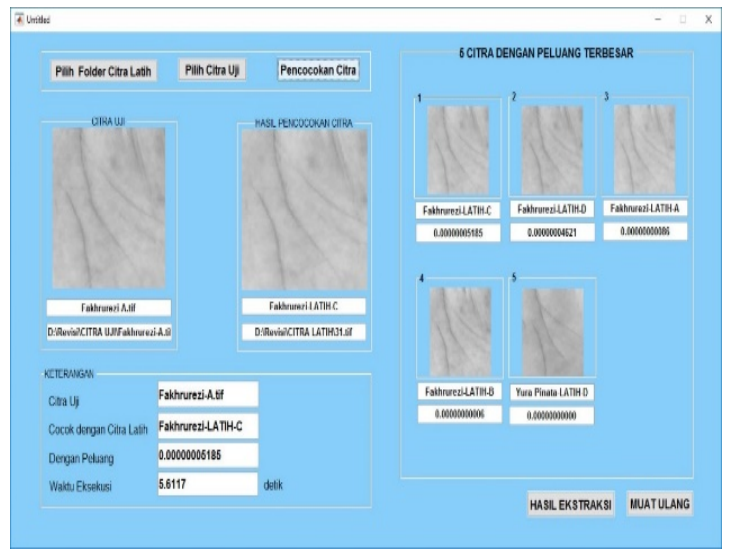

Gambar 5. 13 Citra uji berhasil dikenali dengan tepat

Dari Gambar 5.13 dapat dilihat bahwa citra uji yang berhasil dikenali dengan tepat, ditandai dengan munculnya citra latih dan nama citra yang sama dengan citra uji. Selain itu sistem juga 
Jurnal Pseudocode, Volume IV Nomor 2, September 2017, ISSN 2355-5920

www.ejournal.unib.ac.id/index.php/pseudocode

menampilkan identitas dari citra telapak tangan sebagai informasi mengenai pemilik telapak tangan. Pada bagian kanan interface juga ditampilkan 5 citra latih yang memiliki peluang terbesar beserta dengan nama dan nilai peluang dari tiap citra latih tersebut. Untuk melihat peluang kemiripan antara citra uji terhadap keseluruhan citra latih, maka sistem akan menampilkan grafik pengukuran jarak citra seperti yang ditampilkan pada Gambar 5.18 berikut :

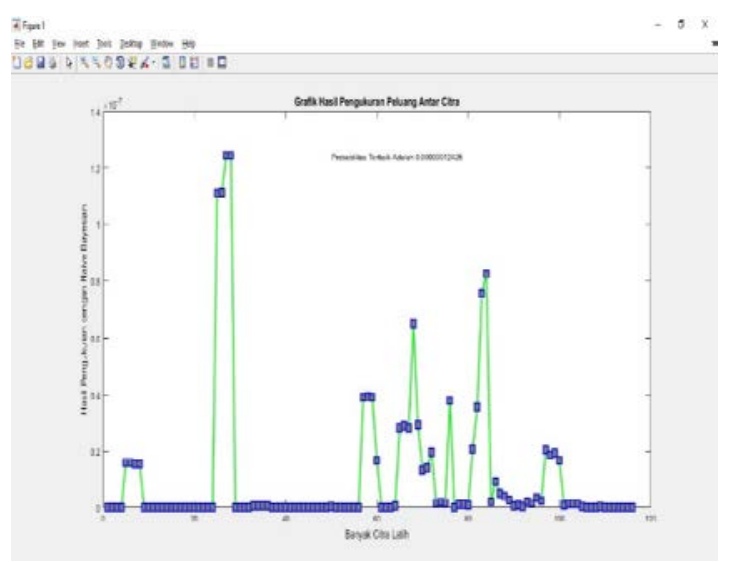

Gambar 5. 14 Grafik pengukuran peluang kemiripan

Dari Gambar 5.14 dapat dilihat bahwa grafik tersebut menyajikan informasi berupa peluang kemiripan antara citra uji terhadap seluruh citra latih, dimana peluang kemiripan terbesar antar citra tersebut sebesar 0.00000005185 sehingga citra tersebut akan ditampilkan sebagai citra yang memiliki peluang kemiripan terbesar dengan citra uji.

Dari Gambar 5.15 dapat dilihat bahwa citra uji yang dipilih gagal dikenali dengan tepat oleh sistem. Hal tersebut ditandai dengan ditampilkannya citra latih yang tidak mirip dengan citra uji. Identitas citra tetap ditampilkan karena hal tersebut merupakan informasi pemilik telapak tangan dari citra latih yang ditampilkan.

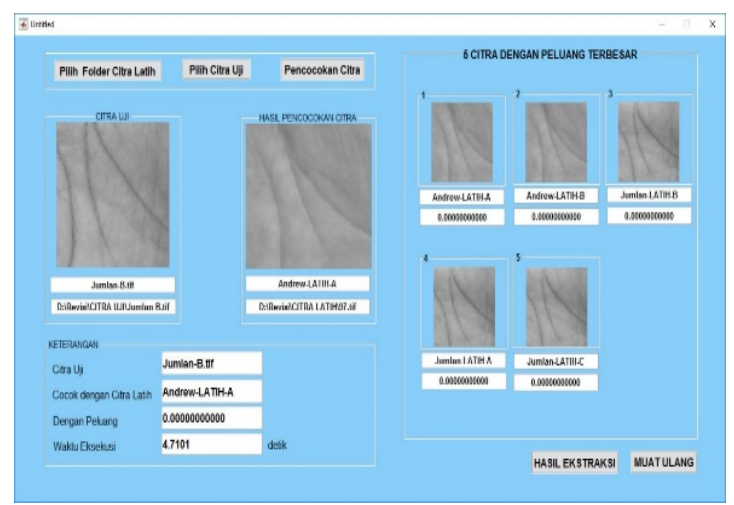

Gambar 5. 15 Citra uji gagal dikenali dengan tepat

Berdasarkan pengujian diketahui bahwa dari 60 citra uji yang diinputkan ke dalam sistem, banyaknya citra yang berhasil dikenali dengan tepat oleh sistem sebanyak 57 citra, sedangkan citra yang gagal dikenali dengan tepat oleh sistem sebanyak 3 citra. Persentase keberhasilan dari metode Linear Discriminant Analysis (LDA) dan Naïve Bayesian menggunakan citra hasil segmentasi menggunakan metode Region of Interest (ROI) adalah sebesar 95\%.

Hasil pengujian 20 citra uji yang diambil dari Casia Palmprint Image Database, nilai akurasi yang didapat sebesar $100 \%$ dan nilai rata-rata peluang 0.00000008019. Sedangkan hasil pengujian 40 citra uji yang diambil secara acak dari lingkungan sekitar, nilai akurasi yang didapat sebesar 92,5\% dan nilai rata-rata peluang 0.00000008988 .

Dalam pengujian ini, sistem dapat salah mengenali suatu citra dikarenakan ketika citra uji tersebut diukur peluang kemiripannya dengan menggunakan naïve bayesian, citra latih yang salah memperoleh peluang kemiripan yang lebih besar daripada peluang yang dimiliki oleh citra latih yang paling tepat untuk citra uji tersebut. Kesalahan tersebut sebelumnya diperoleh dari proses ektraksi, dimana citra uji yang di ekstraksi memiliki kelemahan seperti minimnya pencahayaan dan resolusi citra yang rendah. Hal 
Jurnal Pseudocode, Volume IV Nomor 2, September 2017, ISSN 2355-5920 www.ejournal.unib.ac.id/index.php/pseudocode

ini menyebab kan ekstraksi dari file citra uji tersebut menjadi kurang optimal.

\section{VI.PENUTUP}

\section{Kesimpulan}

Berdasarkan analisa perancangan sistem, implementasi dan pengujiam sistem maka dapat disimpulkan bahwa :

1. Berdasarkan hasil pengujian dari seluruh citra uji dengan citra latih , aplikasi mencocokan citra dengan persentase keberhasilan 95\% pada metode linear discriminant analysis dengan probabilitas metode naïve bayesian.

2. Metode linear discriminant analysis dengan probabilitas naïve bayesian dapat mengenali citra yang diberi noise salt and pepper 0,05 dan blur Gaussian filter 2.5. Hal ini dibuktikan dengan tingkat akurasi masingmasing hasil pencocokan yaitu 93,34 \% dan 93,34\%.

3. Nilai akurasi dari pengujian sampel yang diambil dari CASIA Palmprint Image database adalah 100\%, lebih baik dari citra yang diambil secara acak dari lingkungan sekitar yaitu 92,5\%, namun nilai rata-rata akurasi sampel yang diambil dari CASIA Palmprint Image database adalah 0.00000008019, lebih rendah dari citra yang diambil secara acak dari lingkungan sekitar yaitu 0.00000008988

\section{Saran}

Berdasarkan hasil dan pembahasan yang telah dijabarkan sebelumnya, maka saran yang dapat diberikan untuk pengembangan penelitian selanjutnya adalah sebagai berikut:
Untuk Penelitian lebih lanjut aplikasi mampu melakukan pencocokan langsung melalui kamera webcam.

\section{REFERENSI}

[1] S. Liu and M. Silverman, A Practical Guide to Biometric Security Technology, p. 1, 2001.

[2] A. Muntasa, Pengenalan Pola, Yogyakarta: Graha Ilmu, 2015.

[3] M. C. Wijaya and A. Prijono, Pengolahan Citra Digital Menggunakan MatLAB Image Processing Toolbox., Bandung: Informatika, 2007.

[4] A. Chandra and T. G. Calderon, Toward a Biometric Security Layer, Journal of Information Systems, pp. 51-70, 2003.

[5] A. Linda, Penerapan Region of Interest (ROI) pada Metode Kompresi, Institut Teknologi Bandung, Bandung, 2014.

[6] U. Ahmad, Pengolahan Citra Digital, Graha Ilmu, Bogor, 2005.

[7] D. Sundar, Software Engineering, New Delhi: University Science Press, 2010.

[8] H. Ramza and Y. Dewanto, Teknik Pemrograman Menggunakan Matlab, Jakarta: Grasindo, 2007

[9] D. Putra, "Sistem Biometrika Konsep Dasar," Yogyakarta, ANDI, 2009.

[10] A. Dennis, B. H. Wixom and D. Tegarden, Sistem Analysis and Design with UML Version 2.0, United States of America: John Willey \& Sons, Inc., 2005. 